Prethodno priopćenje UDK 1(045)Platon

doi: $10.21464 /$ fi3 37411

Primljeno 7. 7. 2017.

\title{
Ćiril Čoh
}

Prva gimnazija Varaždin, Preradovićeva 14, HR-42000 Varaždin ciril.coh1@vz.t-com.hr

\section{Matematika i mišljenje svrhe sveg mislivog u Platona}

\begin{abstract}
Sažetak
U tekstu se razmatra Platonovo izlaganje učenja o Dobru u Politeji, te učenje o prvim počelima $u$ Timeju $i$ Fedonu. Pritom se za polazište uzima Platonova tvrdnja da se Dobro može promatrati u njegovom vlastitom mjestu, odnosno u njegovoj chora (Resp. 516b4-7). Takvo motrenje je motrenje Dobra po sebi, a ne u slici ili u prividu. Bijeg u logose u Fedonu nije samo bijeg u govor koji razlaže ideje, nego prije toga, bijeg u logose koji sudjeluju u neprekinutoj analogiji. Ona dominira izlaganjem o prvim počelima u Timeju. Primijenjena na crtu u Politeji preobražava tu crtu iz puke usporedbe s geometrijskim primjerom, u crtu na kojoj se mjesto kao chora razlikuje od mjesta kao topos. Takva crta omogućuje gledanje Dobra u njegovoj vlastitoj chora. Ona pripada jednoj drugačijoj matematici koju možemo nazvati noetičkom.
\end{abstract}

\section{Ključne riječi}

Platon, prva počela, chora, topos, bijeg u logose, neprekinuta analogija, Platonova crta, eidetski brojevi, noetička matematika

\section{Uvod}

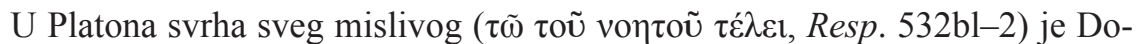

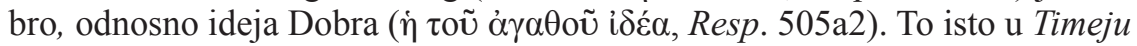


uzrok ( $\alpha i \tau_{i ́ \alpha}$ ) koji sve drži na okupu. Pozivajući se na Platonove tekstove, prije svega na šestu i sedmu knjigu Politeje, Timej i Fedon, želimo razmotriti

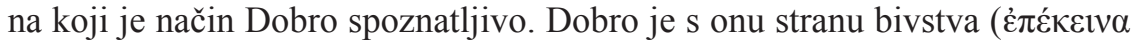
$\tau \tilde{\eta} \varsigma$ oủoías, Resp. 509b10) i tu ga možemo vidjeti. Postavlja se pitanje kakvo je to mjesto koje omogućuje da se Dobro vidi? ${ }^{1}$

U Politeji se pretpostavlja sadržajna odredivost Dobra, vidi se da Sokrat ima određeni nazor o Dobru, koji, istina, ne izlaže, ali razlog zbog kojeg to ne čini nije neizrecivost. U prispodobi s pećinom nedvosmisleno stoji da se Dobro nakon napornog puta može vidjeti kao što se u osjetivom svijetu vidi sunce, da se Dobro može motriti kakvo jest po sebi u njemu srodnom mjestu, u njegovoj

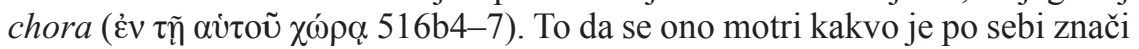
da se ne pokazuje u nekoj slici, nego u sebi samom, te da ovakva spoznaja Dobra nije spoznaja ovog ili onog dobra, dobra za ovo ili za ono, nego dobra

1

To svakako nije neko mjesto u prostoru, nego se od takvog mjesta bitno razlikuje. Nadalje, Dobro jest u tom mjestu da bi moglo biti vid- ljivo, a ne zato da bi se negdje, kao što to vrijedi za svako bivajuće, nalazilo. 
samog po sebi. No što znači da se Dobro spoznaje u njemu srodnom mjestu,

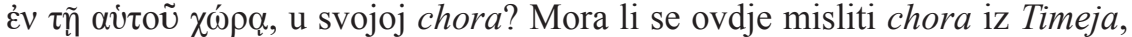

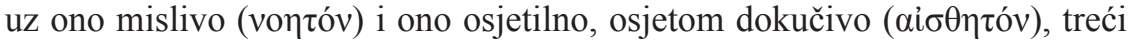
rod bitka?

U Timeju govor o načinu božanskog uređivanja svemira ${ }^{2}$ ne može istinski početi bez uvođenja toga trećeg roda. Sva rasprava od njenog linearnog početka (29a) do njenog pravog početka u drugom dijelu Timeja (47e) trebala bi pokazati što znači raspravljati o prvim počelima bez uvažavanja chore. Zahtjeva li i razumijevanje Dobrog u Politeji uvažavanje tog trećeg roda? Sljedbenici Tübingenske škole ovdje chora prevode kao mjesto u smislu određenog položaja Dobra spram svega ostalog što jest. ${ }^{3} \mathrm{~S}$ druge strane, J. Sallis, izuzetno osjetljiv na Platonovu uporabu te riječi, potaknut diskusijom s J. Derridaom, preispituje što bi ona u ovom kontekstu mogla značiti. ${ }^{4}$ To njihovo preispitivanje vodi nas do Fedona, gdje je također riječ o gledanju Dobra. Međutim, ono se tu ne gleda u svojoj chora, a niti u nekoj slici ili usporedbi, nego u odsutnosti chora, pa se pokazuje u prividu. Takvo gledanje osljepljuje, te ga treba izbjeći, od njega pobjeći u logose. Pod logosima treba razumjeti ne samo govor posredstvom jezika koji je povezan s mišljenjem koje pretpostavlja ideje svega jesućeg te ideju Dobra nego i matematičke logose, koji omogućuju gledanje ideje Dobra u njenoj chora. Spoznaja chore pretpostavlja noetičku matematiku. Ta matematika ne pripada oblasti razuma (dianoia), nego uma (noesis). Oblasti razuma pripada aritmetika, geometrija, astronomija i harmonika, znanja koja čine dianoetičku matematiku. Međutim, njih treba nadići da bi se dosegnula matematika koja omogućuje spoznaju chora i gledanje Dobra u njoj.

\section{Chora i crta podijeljena neprekinutom analogijom kao pretpostavka mogućnosti govora o prvim počelima}

Platon rabi riječ $\chi \omega ́ \rho \alpha u$ u različitim značenjima. Nas interesira značenje koje joj pridaje u kontekstu sedme knjige Politeje i središnjeg dijela Timeja, gdje se ona veže uz promatranje Dobra, odnosno uz mogućnost govora o prvim počelima. U Timeju ona označava rod koji omogućuje razmatranje odnosa mislivog i osjetilnog roda. Slično je i u Politeji. Naime, ukoliko Dobro svezuje osjetilno i mislivo, a može se gledati samo u njegovoj chora, utoliko chora i ovdje označava treći rod. U Fedonu, gdje je također riječ o gledanju sunca, odnosno Dobra, izgleda da Platon ne govori o chora. Istina, on je ne spominje, ali kaže da se sunce, odnosno Dobro, ne može bilo kako gledati i ukazuje na posljedice onog gledanja sunca koje se ne događa u njegovoj chora.

U Fedonu Sokrat traži uzrok, ono što je uistinu dobro i potrebno, što sve veže i drži na okupu, ono u čemu je božanska snaga (Phaid. 99c5-6). Kaže da ga već u mladosti nije mogao sam naći niti od ikoga naučiti. Filozofi prirode, fiziolozi, žele spoznati stvari u izravnom osjetilnom zahvaćanju. Međutim, kad se stvari gledaju izravno, ne zahvaćaju se u onom što je za njih dobro i prikladno, a samo to dobro pokazuje se tako da se prekriva onim što ono nije. Sunce, odnosno Dobro, ne pokazuje se u slici, usporedbi, nego u onom gdje samo Dobro jest. To što samo Dobro jest prekriva se i umjesto njega, na njegovom mjestu pokazuje se što ono nije. ${ }^{5}$ Nema mjesta za pokazivanje Dobra. Uskraćena mu je njegova chora. Da se ne bi oslijepilo, treba pobjeći u logose.

Pod logosima se podrazumijevaju pretpostavke izražene govorom, a time i ideje do kojih kroz govor treba dijalektičkim putem doprijeti. To su ideje pojedinog jesućeg te ideja Dobra. Ali taj bijeg u logose kao pretpostavke koje dovode do ideja podrazumijeva bijeg u logose koji prethode govoru i istom 
daju moć govoru da te ideje dosegne. To su logosi koji sudjeluju u analogiji. Na to nas upućuje Timej, kad se u njemu po prvi puta spominju elementi tjelesnog svijeta: vatra, zrak, voda i zemlja (Tim. 31b6-32a8), ali isto tako i kada Sokrat na Glaukonov zahtjev počinje potpunije i jasnije izlagati ono što je u usporedbi sa suncem samo naznačio, odnos onog osjetilnog i onog mislivog (Resp. 509d-510a10). Razlažući taj odnos na crti, pokazujući na njoj kako je Dobro samom sebi analogno, Sokrat se ne služi samo usporedbom. On Glaukona poziva na gledanje kao slikovno predočivanje, na matematičko razumijevanje geometrijskog prikaza, ali i na umovanje, pri čemu predočivanje i razumijevanje samo prethodi umovanju.

Govoreći o spajanju vatre i zemlje, onog što tjelesnom daje vidljivost i onog što mu daje opipljivost, Platon kaže da se ono treba uspostaviti najljepšom mogućom svezom, a to je analogija. Ona sebe samu i ono što spaja sjedinjuje na najljepši mogući način. Platon nema u vidu običnu analogiju $\mathrm{A}: \mathrm{B}=\mathrm{C}: \mathrm{D}$, kojom se u odnos postavljaju isti omjeri (A : B i C : D) bez zajedničkih članova,

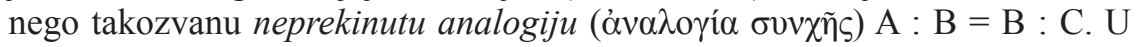
njoj se srednji član (B) odnosi prema posljednjem (C) kao prvi (A) prema srednjem (B). Zato u njoj postavljeni omjeri moraju imati zajedničke članove. Budući da u povezivanju vatre i zemlje ne sudjeluje samo jedan nego dva posrednika, neprekinuta analogija ima četiri člana: $\mathrm{A}: \mathrm{B}=\mathrm{B}: \mathrm{C}=\mathrm{C}: \mathrm{D}$. Ovu četveročlanu analogiju možemo prepoznati i u strukturi podijeljene crte.

Tjelesno, sastavljeno od vatre i zemlje, posredstvom zraka i vode, neprekinutom analogijom postaje vidljivo i opipljivo. Ono mislivo samo po sebi nije osjetivo, ali je umom vidljivo, misli se tako da se umski gleda. To gledanje nije osjetilno, ali mu je srodno. Osjetilno gledanje je slika mišljenja. U gledanju kao mišljenju ponajprije izlazi na vidjelo različitost, ali i jedinstvo i srazmjernost, najprije osjetilne i inteligibilne oblasti, a onda različitost te jedinstvo i srazmjernost unutar svake od njih. ${ }^{6} \mathrm{Da}$ bi govorom kroz jezik doprla do ideja, duša treba moći razabrati različitost te jedinstvo i sabranost. Postiže se to kroz crtu podijeljenu neprekinutom analogijom. Upravo je to chora $^{7} \mathrm{u}$ kojoj se pokazuje Dobro.

U Politeji, na onom mjestu gdje govor o svrsi svega mislivog doživljava svoju kulminaciju, ${ }^{8}$ Sokrat traži od Glaukona da gleda:

2

Govor o božanskom uređivanja svemira u $T i$ $m e j u$, Platonova kozmologija, podrazumijeva govor o prvim počelima.

3

Thomas Alexander Szlezák, Čitati Platona $i$ dva eseja o jedinstvu Platonove filozofije, preveo Borislav Mikulić, Naklada Jesenski i Turk, Zagreb 2000., str. 112.

John Sallis, Platonovo nasljeđe, preveo Davor Ljubimir, AGM, Zagreb 2009., str. 72-83.

Često se previđa da su gledanje sunca u njegovoj chora u Politeji i gledanje pomračenog sunca u Fedonu dva posve različita gledanja. Među ostalim, ovo drugo gledanje, za razliku od prvog, osljepljuje. Ne događaju se oba gledanja uz rizik sljepoće. Taj se previd dogodio i Sallisu. Vidi: J. Sallis, str. 82-83. Prirodu gledanja sunca opisanog u Fedonu pronicljivo obrazlaže J. Stublić. On kaže da se tu sunce gleda u njegovom prividu koji stoji na mjestu sunca samog i sobom ga prekriva. Duša osljepljuje »potpuno neuvjetovanim prihvaćanjem i smatranjem privida najvišim uzrokom«. Vidi: Ivan Stublić, »Sljepoća duše i kretanje«, u: Damir Barbarić, Petar Šegedin (ur.), Platonov nauk o duši, Demetra, Zagreb 2010., str. 47-67., str. 60-61.

6

Usp. Igor Mikecin, »Platonova poiesis«, $F i$ lozofska istraživanja 105 (4/2007), str. 885912 , str. 892 .

7

Imenica $\chi \omega ́ \rho \alpha$ srodna je s glagolom $\chi \omega \rho \varepsilon ́ \omega$ koji znači 'davati prostora', 'hvatati', 'obuhvaćati', te s glagolom $\chi \omega \rho i ́ \zeta \omega$ koji znači 'odvajati', 'lučiti'. Usp. ibid., str. 897, bilj. 26.3.

Glaukon bi želio da se kaže sve što se može reći, a Sokrat smatra da to nije moguće, no da ipak ništa namjerno neće propustiti. Ono što 
»Uzmi dakle na um [vónбov], dovedi pred oči, stvori sliku u mislima, gledaj umom ${ }^{9}$ da jest to dvoje, i da ovo kraljuje mislivim rodom i oblašću, a ono opet vidljivim.« (Resp. 509d1-3)

To dvoje, mislivo i osjetilno gleda se $u$ analogiji koja se postavlja na crti podijeljenoj na dva nejednaka dijela po određenom omjeru (logosu) koji se dalje mora prenijeti u svaki, prvom diobom uspostavljeni dio:

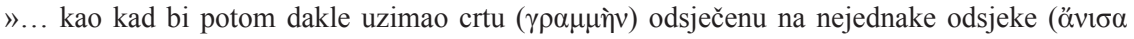

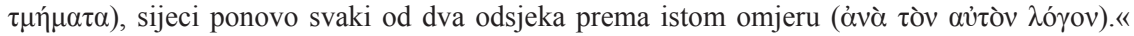
(Resp. 509d6-9)

Ovdje Sokrat poziva Glaukona na gledanje Dobra u slici, u usporedbi s geometrijskim primjerom, ali ga poziva i na razumijevanje toga geometrijskog primjera da bi se kroz to moglo dosegnuti gledanje Dobra u njegovoj chora.

\section{Od matematičkog razumijevanja crte do gledanja Dobrog u njegovoj chora}

Gledanje analogije na Platonovoj crti može biti gledanje Dobra u slici, odnosno u usporedbi. Tako se podijeljena crta uzima kao slika, odnosno primjer iz geometrije da bi se njome slikovito prikazalo nešto negeometrijsko. Takvo gledanje još nije gledanje samoga Dobra u njegovoj chora, nego u slici. Treba nastaviti hod k razumijevanju omjera na crti i preko njega do gledanja Dobra u njegovoj chora na toj istoj crti. Međutim, hoće li se dogoditi gledanje Dobra sàmog ne ovisi samo o crti i na njoj postavljenoj analogiji nego i o onome tko gleda. Prije svega, crta mora biti tako podijeljena da na njoj zaista bude uspostavljen omjer (logos) koji se traži, kako u podjeli na dva nejednaka dijela, tako i u podjeli svakog od tih dijelova. Međutim, onaj tko crtu dijeli mora znati kako će je i zašto dijeliti ${ }^{10}$ da bi se u njoj pokazalo ono što se u njoj može, ali i ne mora, pokazati. Samo takav znalac može biti dijalektičar.

Dijalektičar je onaj tko dohvaća »razlog jestva svakog pojedinačnog « (

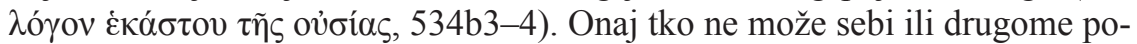
dati razloge ( $\lambda$ ó $\gamma$ ov) nema uma oko toga. Ali, dijalektičar ujedno mora moći govorom $\left(\tau \tilde{\omega} \lambda \lambda^{\prime} \gamma \omega\right)$ razmeđiti ideju Dobra, odvajajući je od svega drugog kao u boju kroz sva pobijanja prolazeći, gorljivo nastojeći da ne pobija prema naziranju, nego prema jestvu, te $u$ svemu tome nepokolebljivo govorom ( $\tau \tilde{\omega}$ $\lambda o ́ \gamma(\omega)$ put prevaljivati. Onaj tko ne može sàmo Dobro razabirati ne može razabrati ni neko pojedinačno dobro. On u životu spava i sanja i prije nego će se tu probuditi stići će u Had i tamo zauvijek zaspati.

Nakon ove usporedbe sa spavanjem i snom slijedi još jedna. Djeca u dijalektici još neodgojena i neobrazovana uspoređuju se s alogosnom crtom. Sokrat pita Glaukona:

»Nego zaista, ako bi svoju djecu koju s govorom odgajaš i obrazuješ, ikad zbilja odgajao, ne bi ih pustio - kako ja smatram - da budući poput crta nerazložiti ( $\alpha \lambda o ́ \gamma o v \varsigma ~ o ̋ v \tau \alpha \varsigma ~ \omega ̋ \sigma \pi \varepsilon \rho ~ \gamma \rho \alpha \mu \mu \alpha ́ \varsigma)$, kao vladaoci u državi budu gospodarima svega onoga najvećeg (534d3-5).«

Ono što uistinu odgaja i obrazuje nije samo govor nego i odgojenikov vlastiti uvid. On mu se govorom ne može dati, nego ga u slušanju govorenog sam mora steći. Uistinu logosan može biti samo onaj tko ono logosno zaista vidi. Onaj tko dijeli Platonovu crtu može se usporediti s tom crtom samom. Ako ne vidi zašto je mora dijeliti na određen način, crta od njega podijeljena neće mu ništa pokazati, on na njoj neće moći razabrati ono što treba razabrati. On je alogosan kao i crta koju je alogosno podijelio, ${ }^{11}$ nije dosegao moć razgo- 


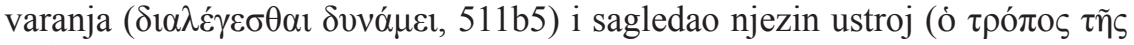

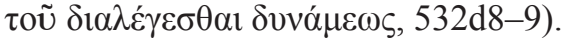

Crta je logosna prije svega onda ako je podijeljena po onom omjeru (ảvò tòv $\lambda$ ó ${ }^{\circ}$ ) koji omogućuje da ono vidljivo i ono mislivo, kao jedno od drugog razlučeno, bude povezano. Probuđena duša vična dijalektici pita se: treba li analogija koju Sokrat u Politeji traži od Glaukona biti ona najljepša moguća sveza iz Timeja ili to može biti bilo koja obična analogija? Ona vidi da upute koje daje Sokrat dozvoljavaju dvije mogućnosti. Prva je da to bude peteročlana analogija $\mathrm{A}: \mathrm{B}=\mathrm{C}: \mathrm{D}=\mathrm{D}: \mathrm{E}, \mathrm{u}$ kojoj prvi i drugi omjer $(\mathrm{A}: \mathrm{B}$ i $\mathrm{C}: \mathrm{D})$ čine običnu analogiju, a drugi i treći (C : D i D : E) neprekinutu (slika 1.).

\begin{tabular}{|l|c|c|c|}
\multicolumn{2}{|c|}{ A ono mislivo } & \multicolumn{2}{c|}{ B ono osjetivo } \\
\hline C predmet noesis & D predmeti dianoja & D' osjetivo biće & E sl.osj.b.
\end{tabular}

Slika 1.

Ono mislivo (A) postavljeno je u odnos prema onom osjetilnom (B), da bi taj isti odnos bio postavljen unutar onog mislivog (C spram D) i unutar onog osjetilnog (D'spram E). Sokratove upute omogućuju da drugi član (B) prvog omjera ne mora biti jednak prvom članu (C) drugog omjera.

Druga mogućnost podjele crte je uspostava četveročlane, pune neprekinute analogije $\mathrm{A}: \mathrm{B}=\mathrm{B}: \mathrm{C}=\mathrm{C}: \mathrm{D}$ (slika 2.), koja odgovara onoj u Timeju (slike 3. i 4.). Odnos većeg dijela crte (A) prema manjem dijelu (B) odgovara odnosu unutar većeg dijela gdje se ponovo pojavljuje B, ali sada postavljen spram C. ${ }^{12} \mathrm{U}$ nastavku se u manjem dijelu ponovno uspostavlja $\mathrm{C}$, ali sad postavljen u odnos spram D. ${ }^{13}$

propušta je govor o samoj crti razloženoj po neprekinutoj analogiji, o chora, uz ono osjetilno i ono mislivo, trećem rodu, bez kojeg se istinski, prirodni početak razlaganja Dobra ne može ni dogoditi. Pri kraju rasprave o Dobru, kad će se ponovo osvrnuti na crtu, Sokrat će izričito reći o kakvom se propustu radi i o razlogu zbog kojeg se dogodio (Resp. 534a). U Politeji nema prostora za nauk o chora. Međutim, ona se tu podrazumijeva. Zato Sokrat na nju i upozorava. Prostor za izlaganje ove teme Platon će naći u Timeju.

9

Glagol vo\&ĩv ne znači samo misliti nego i slikovito sebi predočiti, dovesti pred oči stvoriti sliku u mislima. Interpreti uglavnom smatraju da taj glagol na ovom mjestu ima samo ovo značenje. Usp. Petar Šegedin, Pojam uma u Platona, Matica hrvatska, Zagreb 2002., str. 60-61.

10

Platon je prepustio čitaocu da sam odredi koja su to dva nejednaka dijela na koja se crta dijeli, odnosno koji se to odnos prenosi u svaki od podjelom dobivenih dijelova, pri čemu za odabranu podjelu mora postojati razlog.

11

Ovo mjesto je pravi izazov za interpretaciju. Dugo se mislilo da Platon pod alogosnom crtom misli na inkomenzurabilnu dužinu, npr. na dijagonalu kvadrata. Međutim, kad Platon na drugim mjestima govori o takvim

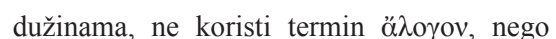

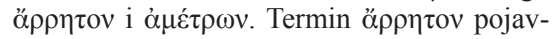
ljuje se u ranijim dijalozima (Hippias maior

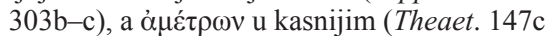
i Leg. 820c). Platon nema razloga inkomenzurabilne dužine nazvati alogosnima. Smatra da je sramota za svakog Grka ne biti upućen u njihovo razumijevanje. Iracionalne dužine $\sqrt{ } 2$ i $\sqrt{ } 3$ sudjeluju u trokutima kao elementima savršenih tijela. Usp. Karl Raimund Popper, Otvoreno društvo i njegovi neprijatelji, preveli Dražen Karaman i dr., KruZak, Zagreb 2003., str. 236-237. Nadalje, Heinrich Vogt je dokazao da se termin ö $\lambda$ oyov za inkomenzurabilne dužine počinje koristiti tek poslije 350. godine pr. Kr. Usp. Željko Marković, Matematika u Platona i Aristotela, str. 107, bilj. 12. T. Heath smatra da se prvi puta pojavljuje u Aristotelovoj Drugoj analitici, 76b9. Thomas Little Heath, A History of Greek Mathematics, sv. 1, Clarendon Press, Oxford 1922., str. 84, 156. Ako se ovdje u logosnosti, odnosno, alogosnosti ne raspoznaje logos po kojoj je crta podijeljena, uzalud se ovoj Platonovoj usporedbi traži smisao.

12

Odsječak B koji je drugi put postavljen, sada spram C, označit ćemo s B'.

13

Odsječak C koji je drugi put postavljen, sada spram D, označit ćemo s C'. 


\begin{tabular}{|c|c|c|c|}
\hline \multicolumn{2}{|c|}{ A ono mislivo } & \multicolumn{2}{|c|}{ B ono osjetivo } \\
\hline B' predmet noesis & $\mathbf{C}$ predmet dianoja & $C^{\prime}$ osjetivo biće & D sl. osj. bića \\
\hline
\end{tabular}

Slika 2.

U Timeju se elementi vatra, zrak, voda i zemlja postavljaju u odnos četveročlane, pune neprekinute analogije. Međutim, nije rečeno treba li se taj odnos promatrati na crti prikazanoj u Politeji (slika 3.) ili pak na crti u kojoj nema prenošenja na početku uspostavljenog odnosa u podjelom uspostavljene dijelove (slika 4.). To su dva bitno posve različita prikaza. U ovom zadnjem se pokazuje nizanje odnosa jednog za drugim. Početnom odnosu vatra - zrak na crti se dodaje odnos zrak - voda, a nakon toga voda - zemlja (slika 4.). Sokrat bi u Fedonu rekao da se ovdje dužine, odnosno na njima postavljeni odnosi, stavljaju jedna do druge da bi tim uzrokom iz jednog nastalo dva (Phaed. 97a6-7). ${ }^{14}$ Takvi brojevi jedan i dva mogu biti brojevi kojima se bavi dianoetička matematika, ali nikako Jedno i Dvojstvo, kojima se izražavaju prva počela.

\begin{tabular}{|c|c|c|c|c|c|}
\multicolumn{2}{|c|}{ A : B } & \multicolumn{2}{c|}{ B : C } & \multicolumn{2}{c|}{ C : D } \\
\hline vatra & zrak & zrak & voda & voda & zemlja
\end{tabular}

Slika 3.

Drugi prikaz odnosa elemenata, onaj na Platonovoj crti (slika 3.), vatru uzdiže na razinu prvog počela koje iz sebe rađa ostale elemente. Rađanje elemenata iz vatre, kroz koje se oni očituju kao njena preobrazba, može se pokazati ukoliko je vidljivo da te elemente vatra već u sebi sadrži. Takovo što može biti vidljivo isključivo na Platonovoj crti.

\begin{tabular}{|c|c|c|c|}
\multicolumn{2}{|c|}{ A vatra } & \multicolumn{2}{c|}{ B zrak } \\
\hline B' zrak & C voda & C' voda & D zemlja
\end{tabular}

Slika 4.

Kao što se nekako samo po sebi podrazumijeva da kod podjele Platonove crte ne treba uvažavati punu neprekinutu analogiju, tako se samo po sebi podrazumijeva da odnose elemenata po punoj neprekinutoj analogiji u Timeju ne treba promatrati na Platonovoj crti. Smatramo da na oba mjesta, i u Politeji i u Timeju treba imati u vidu obje mogućnosti. Radi se o dva posve različita uvida.

Ukoliko na Platonovoj crti uspostavimo neprekinutu analogiju u čitavom nizu, analogiju $\mathrm{A}: \mathrm{B}=\mathrm{B}: \mathrm{C}=\mathrm{C}: \mathrm{D}$, utoliko ćemo uspostaviti jedan izuzetan omjer. To je onaj omjer koji Euklid naziva krajnjim i srednjim omjerom, a danas ga običavamo nazivati zlatnim ili božanskom rezom.

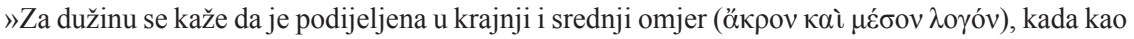
što je cijela prema većem dijelu, tako je veći dio prema manjemu. « ${ }^{15}$

Dakle, ako svezu onog vidljivog i onog mislivog shvaćamo kao najljepšu moguću svezu postavljenu u Timeju te u razdiobi crte slijedimo Sokratove upute, crtu ćemo nužno razdijeliti po krajnjem i srednjem omjeru. ${ }^{16} \mathrm{~S}$ druge strane, nema dovoljnog razloga da se neprekinuta analogija u Timeju nazove najljepšom mogućom svezom utoliko ukoliko se pokazuje samo dodavanjem 
na crti, a ne i diobom Platonove crte. Postavljena dodavanjem odnosa na crti ona bi izražavala bilo koji odnos, a samo slučajno onaj najljepši. ${ }^{17}$

Euklidov naziv za najljepši omjer krajnjih i srednjeg podrazumijeva savršenu sredinu među krajevima. Tim omjerom uspostavljena sredina nije jedan dio između početka i kraja koji bi činili ostale dijelove. Tom sredinom početku i kraju nije nešto oduzeto pa kao treće postavljeno između njih. Ona svakoj od tih dviju suprotnosti daje moć da bude cjelina za sebe unutar cjeline koju čini s onom drugom. Interpreti koji iščitavajući Platonove dijaloge žele dohvatiti Platonovo poimanje odnosa sredine i krajeva opisuju to crtom podijeljenom po krajnjem i srednjem omjeru, ali to ne povezuju s Platonovom crtom. ${ }^{18} \mathrm{Sam}$ Platon nigdje izričito ne spominje krajnji i srednji omjer, ${ }^{19}$ premda mnoga mjesta u dijalozima navode na to da ga poznaje. Razlozi prešućivanja mogu biti oni isti zbog kojih prešućuje izravan govor o samom Dobru.

Platonova rasprava u Politeji o svrsi svega mislivog počinje razdiobom crte. To mjesto ujedno je novi i pravi početak dijaloga Politeja. Sve do toga mjesta iskazano može se smatrati uvodnom pjesmom. Drugi dio Politeje, slično kao drugi dio Timeja, počinje zahtjevom da se počne na pravi, prirodni način. »S obzirom na sveukupnost«, kaže Platon u Timeju, »najvažnije je početi od prirodnog početka« (Tim. 29b). Budući da se na tom početku nalazi razdioba crte, taj pravi početak njena je prava razdioba. Ako se crta podijeli na pravi način, prijeđeno je više od polovice puta ${ }^{20}$ jer je cilj putovanja time osiguran. Ako se počne krivo, na putovanju će se besciljno besputiti.

14

To je onaj isti uzrok o kojem Sokrat govori nekoliko redaka prije gdje kaže da je u mladosti rast živog bića objašnjavao dodavanjem mesa na meso i kostiju na kosti (Phaed. 96c7d5). On hoće reći da živo biće ima sasvim drugačije ustrojstvo od onog koje se svodi na dodavanje.

15

Euklid, Elementi I-IV, prevela Maja Hudoletnjak Grgić, KruZak, Zagreb 1999., VI, def. 3, str. 185 .

16

U literaturi se rijetko povezuje razdioba Platonove crte s najljepšom svezom u Timeju. Zato je i činjenica da se uključivanjem najljepše sveze u razdiobu crte ta crta nužno dijeli po krajnjem i srednjem omjeru gotovo nepoznata. Među rijetkima ističe je S. A. Olsen, koji o tome kaže: »Sada mi se čini jasnim: ako je Platon u prvom redu zainteresiran za neprekinutu geometrijsku proporciju, kako on to očituje tvrdnjom u Timeju 31b-32a, onda postoji jedan i samo jedan način da bi se crta tako podijelila (i to na nejednake dijelove) da odmah imate neprekinutu geometrijsku proporciju. To je podjela po krajnjem i srednjem omjeru ili što mi sada zovemo zlatnim rezom.« Vidi: Scott Olsen, » The Indefinite Dyad and the Golden Section: Uncovering Plato's Second Principle«, Nexus Network Journal 4 (1/2002), str. 97-110, str. 102. doi: https://doi. org/10.1007/s00004-001-0007-8.

17

Mnogi interpreti u najljepšem odnosu u Timeju (Tim. 31b) ne vide bilo koju neprekinutu ana- logiju. Tako Marijan Cipra u njoj prepoznaje zlatni rez kao »vrhunac proporcionalne razmjernosti«. Vidi: Marijan Cipra, Metamorfoze metafizike, Matica hrvatska, Zagreb 1999. str. 133. Roger Herz-Fischler među ostalima navodi P. Michela, koji govoreći o spomenutom odlomku kaže: »Koliko mnogo veća bi bila harmonija u razmjeru kada bi zbroj dvaju članova bio jednak trećem (to jest, kad bi podjela bila po krajnjem i srednjem omjeru).« Vidi: Roger Herz-Fischler, A Mathematical History of the Golden Number, Dover Books, New York 1998., str. 85. Međutim, da bi se taj odnos ovdje mogao prepoznati kao zlatnorezni, potrebno ga je povezati s razdiobom crte. U protivnom je to povezivanje bez pokrića.

18

Jedan takav opis ćemo naći u tekstu I. Mikecina u kojem je riječ o demonskom kretanju duše između suprotnosti, odnosno krajnjosti u Simpozijumu. Vidi: Igor Mikecin, »Sustav duše«, u: Damir Barbarić, Petar Šegedin (ur.), Platonov nauk o duši, Demetra, Zagreb 2010., str. 151-216, str. 190.

19

Proklo u svojim komentarima prve knjige Euklidovih Elemenata spominje rez ( $\tau$ o $\mu$ ó $\varsigma$ ) koji ima svoje podrijetlo u Platona, no nije sigurno da pritom misli na krajnji i srednji omjer. Usp. Herz-Fischler, nav. dj., str. 90.

20

Platon u Zakonima varira pitagorovsku misao da je početak polovica svakoga djela, dodajući da je hvale vrijedan dobar početak. Zatim 
Podjelom crte po krajnjem i srednjem omjeru dobivaju se nove značajke za kojima prema nekim interpretima nema potrebe tragati ili se uopće ne može dokazati da ih ima. ${ }^{21}$ Segment onog osjetilnog $\left(C^{\prime} D\right)$ jednak je segmentu onog umljivog (B'). Odsječci stvari i slike stvari unutar segmenta onog osjetilnog svojom dužinom ulaze u odsječak onog umljivog. Crta je postala simetrična. Odsječak C nalazi se točno u njenoj sredini. Zato odsječke onog osjetilnog $\left(\mathrm{C}^{\prime}{ }_{\mathrm{i}}\right.$ D) možemo preslikati u odsječak onog umljivog, čime se Platonova crta siječe, ne samo na četiri nego i na pet dijelova. Nadalje, na crti razloženoj prema neprekinutoj analogiji, veći dio se prema manjem odnosi kao oba zajedno prema većem. Smatramo da ove značajke otvaraju neke nove mogućnosti interpretacije koje s velikom vjerojatnošću nadopunjuju nedorečenost Platonovih spisa.

Ukoliko se crta podijeli tako da se veći dio postavlja prema manjem kao oba zajedno prema većem $\left(\mathrm{A}: \mathrm{B}=\mathrm{AB}: \mathrm{A}\right.$, odnosno $\left.\mathrm{B}^{\prime} \mathrm{C}: \mathrm{C}^{\prime} \mathrm{D}=\mathrm{B}^{\prime} \mathrm{CC}^{\prime} \mathrm{D}: \mathrm{B}^{\prime} \mathrm{C}\right)$, utoliko se pokazuje da veći dio u sebi nosi manji, što mu daje mogućnost da ga iz sebe izvede. To izvođenje iz sebe na Platonovoj se crti pokazuje kao rađanje. Sunce je porod Dobra začet srazmjerno njemu samom. Isto tako ono osjetilno je porod onog mislivog. Sokrat kaže Glaukonu da uzme to dvoje koje je promišljao u odnosu sunca i Dobra i da ih sada gleda. A gledati ih može na crti, naravno ako je ona na dobar način podijeljena. Na crti koja je na krivi način podijeljena (slika 1.) nema mjesta (chora) za porod, nema primateljice i njegovateljice onog rođenog pa se ono mislivo ne može poroditi. Izričaj da je sunce porod Dobra začet srazmjerno njemu samom upravo upućuje na srazmjer kao ono što taj porod omogućuje.

Sunce kao porod Dobra ujedno je i slika Dobra. Slika je izvedena iz onog što prikazuje kao što je ono rođeno izvedeno iz onog koje rađa. Tako ono mislivo u odsječku onog umljivog iz sebe u odsječak onog razumljivog izvodi sliku koja je ujedno i porod. Matematika je slika dijalektike i to takva slika dijalektike koja je ujedno i njezin porod. Zbog toga je i moguće upravo kroz matematiku dosegnuti dijalektiku. ${ }^{22}$ Međutim, kroz matematiku se može dosegnuti dijalektika ne zato što bi dijalektika u njoj bila prisutna, nego obrnuto. Matematika je prisutna u dijalektici kao njen niži, njoj podređen oblik. Zbog svega toga je uspon od matematike prema dijalektici izuzetno težak. Taj put je suprotan rađanju kao prirodnom putu.

Na crti je moguća i slika koja nije porod. Tako slika onog osjetilnog u najnižem odsječku crte nije ujedno i porod onog osjetilnog. To je samo slika i ništa više od toga. Ona je nepokretna i nema ničeg u njoj što bi je moglo pokrenuti prema onom iz čega je proizašla. ${ }^{23}$ Matematika može također biti na istoj razini nepokretnosti, neuzgibanosti. Odvojena od onog iz čega je rođena preokreće se u ono što na putu mišljenja više ne vodi prema onom najvišem. Sama se proglašava onim najvišim prekrivajući sobom, kao u pomrčini sunca, ono što bi se tek napornim putem iz nje moglo dosegnuti.

Platonova crta podijeljena je po logosu utoliko ukoliko je podijeljena po krajnjem i srednjem omjeru. Međutim, takva podjela za uspostavu logosne crte nije dovoljna. Ispravno podijeljena crta ne pokazuje ono što treba pokazati ako se vidi samo kao geometrijska crta, kao veličina podijeljena na veći i manji dio. Na takvoj je crti postavljeno mjesto, topos, ali ne i chora. Na njoj se razlikuje veliko i malo, gore i dolje, lijevo i desno, ali ne i vidljivo i mislivo, slika i ono odslikano, rođeno i rađajuće. Ukoliko se pak na takvoj crti gleda vidljivo i mislivo, utoliko je onda to samo gledanje kroz sliku ili usporedbu. $\mathrm{Na}$ crti treba gledati ono vidljivo i ono mislivo, ne u slici, nego u njihovoj chora. Ukoliko duša na crti vidi samo topos, utoliko je ona slijepa, nerazborita, alogosna. 
Platon u Fedonu, u kontekstu govora o potrebi bijega u logose spominje dvije ideje kao primjer onoga što bi razgovor o prvim počelima trebao dosegnuti. To je ideja lijepog i ideja velikog, odnosno malog. Nešto je lijepo ako sudjeluje u ljepoti, nešto je veliko ili malo ako sudjeluje u velikosti ili malenosti. Ideja lijepog prikazana na crti može se dosegnuti samo u svojoj chora. Međutim, da bismo na crti prikazali veliko i malo ne trebamo tu crtu gledati kao chora, nego samo kao topos. Podjelom crte na dva nejednaka dijela uspostavlja se upravo veliko i malo. U dijeljenju crte u kojem se razlaže samo veliko i malo nema odnosa odslikavanja i rađanja. Ideja velikog i malog nema svoj porod. Crta na kojoj se razlikuje veliko i malo podijeljena je na dva različita mjesta (topos). Crta na kojoj razlikujemo ono lijepo i njegov porod također je podijeljena na dva različita mjesta, ali i na dva različita područja. Da bi pokazala dva različita područja, crta se mora misliti ne samo kao topos nego i kao chora.

\section{Prva počela i broj}

Govoreći o ideji velikog i malog Sokrat spominje brojeve. Brojevi se razlikuju jedan od drugog po tome što je jedan veći, a drugi manji. Nadalje, brojem se određuje i koliko je neki broj veći od drugog broja. Navodi se primjer brojeva 8 i 10. Promatrajući njihov odnos ne vidimo samo da je broj 8 manji od broja 10 nego i to za koji je to broj 8 manji od 10. Izgleda da se brojevi odnose samo na veliko i malo, da oni s idejom Dobra nemaju veze. Svakako, brojevi koji se međusobno razlikuju samo po veličini nemaju veze s Dobrim. Međutim, brojevi se ne razlikuju međusobno samo po veličini. Kao što je onaj tko na crti

nastavlja: »No, početak je, kako se meni čini, više od polovice, te ako on pođe za rukom, nitko ne može to riječima dovoljno pohvaliti.« $(\operatorname{Leg} .753 \mathrm{e})$

21

Tako K. M Sayre kaže: »Moguće je (ali, jedva) da je Platon u konstrukciji podijeljene crte imao na umu zlatni rez (ili zlatni pravokutnik) i misao o njegovim jedinstvenim estetskim kvalitetama koje na neki način reflektiraju Dobro kao ideal ljepote. Komentator $\mathrm{u}$ to uvjeren imao bi golem posao u svojim rukama da pronađe smisao proširene jednakosti $\mathrm{A}: \mathrm{B}=\mathrm{C}: \mathrm{D}=(\mathrm{A}+\mathrm{B}):(\mathrm{C}+\mathrm{D})=(\mathrm{C}+\mathrm{D})$ : $(\mathrm{A}+\mathrm{B}+\mathrm{C}+\mathrm{D})$, koja proizlazi iz te interpretacije.« Kenneth M. Sayre, Plato's Late Ontology: A Riddle Resolved, Princeton University Press, New York 1992., str. 304. Napomena: U našem prikazu (slika 2.) tu proširenu jednakost koju spominje Sayre, zbog drugačijeg označavanja, izražavamo kao $\mathrm{D}: \mathrm{C}^{\prime}=\mathrm{C}: \mathrm{B}=$ $\left(\mathrm{D}+\mathrm{C}^{\prime}\right):\left(\mathrm{C}+\mathrm{B}^{\prime}\right)=\left(\mathrm{C}+\mathrm{B}^{\prime}\right):\left(\mathrm{D}+\mathrm{C}^{\prime}+\mathrm{C}+\mathrm{B}^{\prime}\right)$ Sayre kaže da Platon ističe da se odsječci unutar kraćeg dijela (D:C') odnose kao odsječci unutar dužeg dijela (C:B), odnosno kao kraći dio $\left(\left(\mathrm{D}+\mathrm{C}^{\prime}\right)\right.$ prema dužem dijelu $(\mathrm{C}+\mathrm{B}$ ') . Međutim trebali bismo pronaći razlog zašto bi se duži dio (C+B') prema čitavoj dužini crte $(\mathrm{D}+\mathrm{C}$ ' $+\mathrm{C}+\mathrm{B}$ ') također trebao odnositi prema tom istom odnosu. Platon taj odnos, misli Sayre, nigdje ne spominje i ne daje razloge za njegovo postavljanje. U tekstu koji neposredno prethodi ovome, Sayre ispituje koji to brojevi mogu zadovoljiti jednakost $\mathrm{A}: \mathrm{B}=\mathrm{C}$ :
$\mathrm{D}=(\mathrm{A}+\mathrm{B}):(\mathrm{C}+\mathrm{D}) \mathrm{s}$ konsekvencom $\mathrm{B}=\mathrm{C}$. Time, možda ne htijući, pokazuje da nije tako lako odrediti te brojeve. Pitamo se, jesu li Sokratovi sugovornici mogli bez većeg napora to učiniti? Iz Platonovog teksta se ne vidi da bi Glaukon u konstrukciji crte naišao na neki poseban problem. Velika je vjerojatnost da je ta konstrukcija u Platonovom krugu bila dobro poznata i da se Sokrat na nju prešutno poziva. Ona je uključena u izvedbi pentagrama, pitagorovskog znaka raspoznavanja.

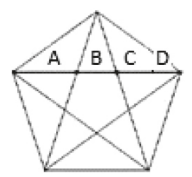

U svakoj od pet linija pentagrama može se prepoznati odnos većeg dijela $(\mathrm{AB})$ prema manjem (CD) koji je jednak odnosu dijelova A i B unutar većeg dijela. Potrebno je još taj odnos dijelova odrediti unutar manjeg dijela. To nije poseban problem jer je veći dio manjeg dijela već poznat $(\mathrm{C}=\mathrm{B})$.

22

Da je obrnuto dijalektika bi bila doseziva iz matematike.

23

Sužnjevi u pećini gledaju u slike i nemoćni su okrenuti se i pokrenuti se prema izvoru iz kojeg slika dolazi. 
vidi samo veliko i malo slijep za gledanje ideje Dobra, tako je za to isto slijep onaj tko u brojevima 8 i 10 vidi samo dvije veličine i njihovu razliku.

Postoje brojevi koji se ne razlikuju samo po veličini, s kojima se ne računa.

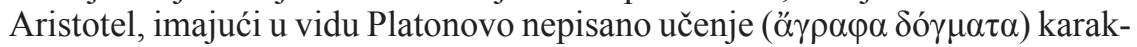

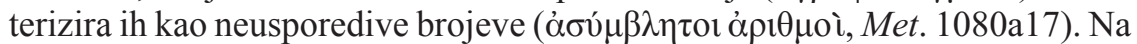
drugom mjestu kaže da je u nizanju tih brojeva jednog iza drugog svaki vrstom različit (Met. 1083a34 i 1080b11). Kao takvi razlikuju se od matematičkih brojeva pa se još nazivaju eidetskim brojevima. ${ }^{24}$ Oni se odnose na Dobro. Upravo stoga se Dobro u Platonovom nepisanom učenju naziva i onim Jednim.

Dobro se može motriti u svojoj chora i kao broj, odnosno, ustroj brojeva. Naime, sámo Dobro kao Jedno u svojoj se chora pokazuje u razlici spram sebi suprotnog neodređenog dvojstva i s brojevima koje ta dva principa iz sebe rađaju. Noetički brojevi ne nižu se u beskonačnost, nego samo od 1 do 4, a prema Aristotelovom svjedočanstvu (Phys. 206b32) ima ih deset. Taj sklop se naziva tetraktys, a najčešće se pokazuje kao slijed dimenzija od točke preko crte i plohe do tijela. Njime se tumači rađanje svega postojećeg. U dijalozima Platon o tome šuti ili govori na skriven način, ${ }^{25}$ kao npr. u Zakonima:

»Nastaje li postanje svega kad god se zbude neka trpnja? - Ta očigledno onda kad neki početak, zadobivši uvećanje, stupi u drugi prijelaz, a iz njega opet u sljedeći, te prošavši sva tri bude zamjetljiv onima što zamjećuju. Sve nastaje mijenjajući se tako i krećući se; ono istinski jest dok miruje, no čim se mijenja u neko drugo stanje, posvema propada. « (Leg. 894a1-8)

Pretpostavljamo da brojevi 10 i 8 spomenuti u Fedonu upućuju na noetičku dekadu i na muzičku oktavu. Tetraktys ne upućuje samo na broj 10, nego i na broj 8. Unutar intervala oktave između prvog i osmog tona nalaze se intervali kvinta, između prvog i petog, te kvarta između petog i osmog. Tonovi, premda određeni brojevima, ne razlikuju se međusobno samo po veličini. Da je tako, muzika ne bi mogla izražavati misli i osjećaje, kroz nju bi se moglo samo računati. Pretpostavljamo da su noetički brojevi, oni unutar dekade postavljeni na sličan način kao tonovi unutar oktave. Zbog toga su muzička oktava, premda ima osam članova, i noetička dekada, premda ima deset članova, sličnog ustroja. Ne pripadaju matematici, nego području iz kojeg se rađa matematika u području razumijevanja, tj. noetičkoj matematici.

\section{Dobar početak govora o prvim počelima i izlaganje o savršenim geometrijskim tijelima}

Gledanje Dobra u njegovoj chora događa se u neprekinutoj analogiji crte ukoliko se na crti razabire razlika između velikog i malog, vidljivog i mislivog, mjesta u smislu topos i mjesta u smislu chora. Tada se ono pokazuje i kao broj koji iz sebe rađa noetičku dekadu, odnosno muzičku oktavu, svrhu svega mislivog. ${ }^{26}$ Međutim, broj kao svrha ujedno je i ono prvo, ono na početku. Zbog toga rasprava kroz jezik koja ga hoće dosegnuti, uvijek zaostaje. To se vidi kako u Politeji tako i u Timeju. Kada počinjemo s čitanjem Timeja, kaže Sallis, odmah uviđamo da nismo na samom početku. ${ }^{27}$ Početak se urušava ukazivanjem unatrag, na drugi početak, na diskusiju od prethodnog dana koja bi trebala biti nastavljena upravo u ovoj koja se upravo odvija. Nadalje, treba promisliti čitav prvi dio Timeja da bi se tek u drugom dijelu, zahvaljujući prodoru kroz prvi, moglo sve rečeno nanovo, sada s pravim početkom, promišljati. Ali ipak, na samom početku teksta upozorava se na početak i to onaj za kojeg rekosmo da se pokazuje u neprekinutoj analogiji crte. To je broj, onaj noetički iz kojeg se rađa noetička dekada, odnosno muzička oktava. On se tu 
ne pokazuje, ali se na njega ukazuje. Sokrat na početku dijaloga prebrojava one koji su ga ugostili, odnosno primili.

»Jedan, dva tri; a četvrti, dragi Timeju, gdje nam je četvrti, od jučerašnjih gostiju a današnjih domaćina gozbe.« (Tim.17a1-3)

Smatramo da četvorica čine cjelinu kako u jučerašnjem tako i u današnjem razgovoru. Ona je izražena brojem, ne bilo kojim, već četvorstvom, tetraktysom.

Novo ukazivanje na početak nalazi se na početku drugog dijela dijaloga. U prvom dijelu razlaže se postanak kozmosa kao djelo uma. U drugom dijelu u

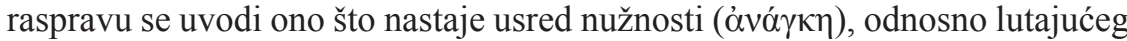

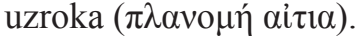

»Zato se treba vratiti unatrag pa uzevši drugačije načelo, svojstveno upravo ovom predmetu, započeti o njemu raspravu od početka.« (Tim. 48b2)

Timej priziva boga zaštitnika za novi početak njegovog govora. Potrebno je poduzeti potpuniju podjelu bića od one prethodne. Uz ono umno, uzor koji uvijek jest na isti način, te uz odraz uzora koji je vidljiv i nastaje treba razlučiti

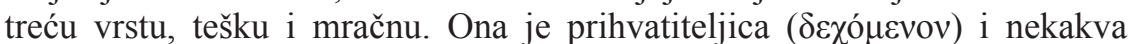

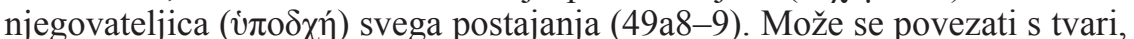
ali nije tvar. ${ }^{28}$ Može se povezati s prostorom (topos), ali nije prostor. Može se usporediti sa zemljom, zrakom, vatrom i vodom (51a), ali nije ništa od toga, »već nekakva nevidljiva i bezoblična vrsta koja sve prima, a na neki zamršen i teško uhvatljiv način sudjeluje u onom umnom«.

Ovim uspoređivanjem chora s elementima, Timej kao da nas potiče da nastavimo promišljanje. Naime, uz zemlju, zrak, vatru i vodu vežu se pravilna tijela: kocka, oktaedar, tetraedar i ikosaedar, a ta treća vrsta nije ništa od toga

24

U Filebu Platon razlikuje dvije aritmetike, od kojih jedna pripada mnoštvu, a druga filozofima (Phil. 56d4-57a2). Zamjetljive brojeve koje zamjećuju mnogi treba razlikovati od eidetskih brojeva. Eidetske brojeve možemo zvati noetičkim brojevima, a matematičke brojeve dianoetičkim. Time se njihov međusobni odnos upućuje na onaj naznačen na Platonovoj crti. Matematički, odnosno dianoetički brojevi pripadaju području razumijevanja, a noetički području umovanja. 25

Usp. T. A. Szlezák, Čitati Platona i dva eseja o jedinstvu Platonove filozofije, str. 73.

26

Od crte vodi put do noetičkih brojeva. Mnogi interpreti su strukturu četvorstva, odnosno tetraktysa, naznačili na crti sličnoj onoj prikazanoj u Politeji. Unutar odsječaka onog mislivog prepoznali su brojeve 1 i 2 , a unutar odsječaka onog osjetivog 3 i 4. Pozivajući se na Aristotelov tekst De anima 404 b16-27, te na komentatore Simplicija i Filopona, Konrad Gaiser tu povezanost naznačava u dva niza, jedan vodoravni, a drugi okomiti. Gledano okomito na vrhu je broj 1, koji se odnosi na područje ideja (Ideenwelt), zatim slijede brojevi 2 i 3, koji se odnose na područje duše
(Seele), i konačno područje osjetilnih pojava (Erscheinungen). Idejama pripadaju brojevi kao najviši principi (Eins, Zwei, Drei, Vier), području duše njezine moći vezane uz dimenzije: nous u dimenziji jedinstva (Einheit), episteme u dimenziji dužine (Länge), doksa u dimenziji širine (Breite) i aisthesis u dimenziji dubine (Tiefe). Području osjetilnih pojava pripadaju točka (Punkt), dužina (Linie), ploha (Fläche) i tijelo (Körper). Usp. Konrad Gaiser, Platons ungeschriebene Lehre. Studien zur systematischen und geschichtlichen Begründung der Wissenschaften in derplatonischen Schule, Ernst Klett Verlag, Stuttgart 1967., str. 44-51.

27

J. Sallis, Platonovo nasljeđe, str. 54

28

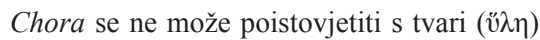
U svezi toga Sallis kaže: »Jedna od slika kojom se prispodobljuje chora je slika zlata $u$ koje se mogu utisnuti svi oblici, ali koje samo o sebi nije nijedan od tih oblika i ne može biti nijedan od njih ukoliko treba biti jednako prihvatiteljsko prema svima - to je samo slika chore.« Vidi: J. Sallis, Platonovo nasljeđe, str. 51. 
nego takav oblik ${ }^{29}$ koji prima sva ta četiri oblika (51a1), ${ }^{30}$ a na neki zamršen i teško uhvatljiv način sudjeluje i u kugli. Chora nije ni zemlja, ni zrak, ni vatra, a prema tome nije ni kocka, ni oktaedar, ni tetraedar, ni ikosaedar. A

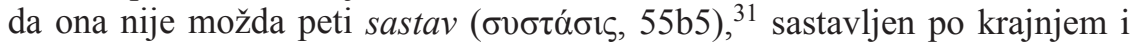
srednjem omjeru - dodekaedar (55c7-9)?

Timej treću vrstu nije nazvao ni materijom, ni mjestom, ni nekim elementom različitim od vatre, zraka, vode i zemlje. S materijom je možemo uspoređivati, od prostora (topos) je treba strogo razlikovati. Kad je postavljamo u odnos s elementima vatre, zraka, vode i zemlje kao onim osjetilnim s jedne strane i s kuglom kao onim umnim ${ }^{32} \mathrm{~s}$ druge strane, onda je ona u tom odnosu ono treće. ${ }^{33}$ Ono treće jest dodekaedar u onoj mjeri u kojoj su četiri pravilna tijela ono osjetilno, a kugla ono umno. Nakon napornog promišljanja svih ovih distinkcija Timej se odlučio ovaj treći rod nazvati chora. Taj dio teksta Timeja u kojem se opisuje chora $(52 \mathrm{~b}-\mathrm{d})$ Sallis je nazvao horologijom. Time je iz nje isključio tekst koji slijedi, što smatramo pogrešnim.

Izlaganje koje slijedi u nastavku o stvaranju kozmosa uvođenjem trokuta i pravilnih tijela način je mišljenja kojim se uvažava ovaj treći rod. To je jedan izuzetan način mišljenja, nepravo zaključivanje u odsustvu svakog osjetilnog opažanja tako da se jedva u njega može vjerovati (52b4). Ono što chora prima i pokazuje gledamo kao u nekom snu. Premda budni, nismo ju u stanju razlučiti, posebno od prostora (topos). Gledanje se događa u mediju geometrije ukoliko se prostor (topos) njome posredovan može naći u razlici i jedinstvu s onim što nazivamo chora. Ono pretpostavlja dobro poznavanje geometrije (53c1-7), ali i gledanja kao u snu. Gledamo kao u snu, ali ono što vidimo pokazuje nam se kakvo uistinu po sebi jest.

U ovom se gledanju, da bi ga uopće i bilo, mora razlikovati kugla od pravilnih tijela. Kugla nije ono tjelesno, nego ono umno. Nadalje, unutar pet različitih sastava treba odvojiti četiri tijela od sastava koji nije tijelo, nego prihvatiteljica tjelesnog, a na neki zamršen i teško prihvatljiv način i onog umnog. Platon kaže da ga je Bog upotrijebio za svemir, »oslikavajući na njemu likove« (Tim. 55c7-9). Sve ostale sastave, trokute koji se nalaze u njihovom ustroju Platon je podrobno izložio, a o ovom sastavu i trokutu po kojem je ustrojen šuti. Pretpostavljamo da to nije zato što o tome ne bi imao razloga govoriti.

Platonovo izlaganje postanka kozmosa počiva na geometrijskim načelima. To su trokuti koji su u ustroju četiriju pravilnih tijela i petog sastava. Međutim, ta načela nisu najviša. Postoje viša načela od ovih (Tim. 53d9-11). Njih treba tražiti u područjima koja su određena slijedom dimenzija, odnosno tetraktysom. Pravilna geometrijska tijela povezana elementarnim trokutima jedno su od triju područja i to zadnje u nizu. Prethodi im područje pravilnih, u krug upisivih geometrijskih likova povezanih elementarnim dužinama te područje dužina i brojeva odnosno dužinama izraženih brojeva. ${ }^{34}$ Horologija geometrijskih tijela izložena u Timeju navještava savršeniju horologiju geometrijskih likova i dužina i onu najsavršeniju koja se odvaja od svega predočivog, horologiju noetičkih brojeva. Sve tri zajedno čine noetičku matematiku.

\section{Izoštravanje gledanja i izlaganja Dobra kroz pokušaj novog započinjanja}

Govorom kroz jezik uspostavlja se razumijevanje. U njemu se spoznaje istina Dobra i svega pojedinačnog. Tu moć nema on po sebi, nego je dobiva dohvaćanjem moći razgovaranja. Moć razgovaranja ima svoj ustroj koji se mora raspoznati, odnosno, vidjeti. Do gledanja ustroja u kojem se pokazuje Dobro 
dolazi se vježbanjem kroz odgoj i obrazovanje u granama matematike (Resp. 533a7-10). Međutim, one nisu učenje o tom ustroju, nego samo otvaranje prostora u kojem se on može očitovati. Taj ustroj u matematici se pokazuje tako da se ukazuje na njegovu odsutnost. Matematika svojim različitim granama može i treba poslužiti i drugim svrhama. Na putu uspona do gledanja ustroja u kojem se pokazuje Dobro, te druge svrhe treba od ove najuzvišenije najoštrije odvojiti.

29

Chora jest bezoblična da bi mogla primit likove vatre, zraka vode i zemlje. Ona jest bezoblična, što znači bez svih onih likova koje će ikad primiti (50d7). Međutim, ona ipak jest nekakav oblik ( $\varepsilon \tilde{i} \delta$ ós). Možda na to

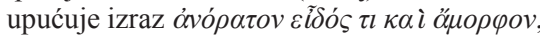
- neki nevidljivi $i$ bezoblični vid, ideja, odnosno oblik (51a6). Spomenimo da nasuprot tome Taylor u svom komentaru Timeja

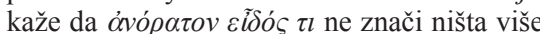

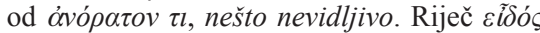
je ovdje puka perifraza. Usp. Alfred Edward Taylor, A Commentary on Plato's Timaeus, Clarendon Press, Oxford 1928., str. 330.

30

Platon ne kaže izričito da chora prima četiri tijela. Neki interpretatori misle da Platon ovdje hoće reći da chora u sebe prima sve što postoji. Cornford se u svom komentaru Timeja ipak odlučuje za četiri tijela. Usp. Francis MacDonald Cornford, Plato's Cosmology. The Timaeus of Plato, Hackett Publishing Company, Indianapolis, Cambridge 1935. ( $\left.{ }^{2} 1997.\right)$, str. 186, bilj. 2. Takvo čitanje prihvaćaju Paulsen i Rehn. Usp. Damir Barbarić, Skladba svijeta: Platonov Timej - tekst izvornika s hrvatskim prijevodom, uvodom te filološkim i filozofskim komentarom, Matica hrvatska, Zagreb 2017., str. 290.

31

Za četiri pravilna geometrijska tijela Pla-


$(\sigma \tilde{\omega} \mu \alpha)$, a ukazujući na dodekaedar naziva ga samo sastavom. Treba ga shvatiti kao na poseban, lijep način složenu kompoziciju koja kao takva na lijep način (51a) hraniteljski, njegovateljski, majčinski, prima četiri tjelesa, a na zagonetan način (51a7) i kuglu kao ono umno. Ovakav prostor teško je predočit i misliti. Vjerujem da se tom poduhvatu približio Salvador Dali u svojoj slici Sakrament posljednje večere (dostupno na: https://www. dalipaintings.com/the-sacrament-of-the-lastsupper.jsp; posljednji pristup: 7. 7. 2017.) $\mathrm{Na}$ ovoj slici posljednja večera ne prikazuje se u biblijskoj gornjoj sobi, u nekom realnom prostoru, nego upravo u dodekaedru. On kao brod plovi morskim zaljevom istovremeno uzdignut prema nebu. Isus i učenici sjede za stolom Platonovom crtom podijeljenom na pet dijelova. Podjela stola je određena jednom od linija pentagrama na posebno istaknutoj plohi dodekaedra. Učenici su raspoređeni u četiri grupe po tri. Svakoj grupi pripada jedan od pet dijelova stola. Pognutih glava i u dubokoj sabranosti učenici na lijevoj strani ne razlikuju se po liku i položaju od onih na desnoj strani. Među njima je uspostavljena zrcalna simetrija. Isus se nalazi u središnjoj poziciji i to u dva lika. Kao čovjek sjedi za stolom a kao Bog uzdignut je prema nebu. Ovaj prostor upravo omogućuje povezivanje neba sa zemljom, božanskog sa ljudskim. U ovom prostoru kruh i vino nisu samo kruh $\mathrm{i}$ vino već tijelo i krv Isusova koje se svima razdaje i tako ih povezuje u puno jedinstvo. 32

Tvoreći tijelo svijeta bog stvara vatru, zemlju, vodu i zrak, odnosno prvotna tijela od kojih je sazdano sve osjetilno, te tvorbu dovršava time što tijelu svijeta daje oblik kugle. Usp. I. Mikecin, »Platonova poiesis«, str. 899, bilj. 13. Kugla u ustroju svijeta nije ono osjetilno, nego božansko, ono mislivo. Kugla je ono božansko u svijetu, kao što je um ono božansko u čovjeku. Imajući um u sebi čovjek postaje božanski. Usp. ibid., str. 899. Slično tome po obliku kugle božanski postaje svijet. 33

»Ona je treći rod koji ograničava i uz to tek čini mogućim ono cirkuliranje između ostala dva roda koje se naziva poiesis.« Usp. J. Sallis, Platonovo nasljeđe, str. 66.

34

Komentirajući Tim. 53d, Cornford tvrdi: »Ako plohe mogu biti konstruirane iz trokuta, trokuti za sebe mogu biti konstruirani iz dužina, a dužine mogu biti izražene brojevima«. To sugerira, nastavlja Cornford, da bi viši principi, poznati matematičarima bili dužine $i$ brojevi. Platon ne razlaže te više principe jer je njegov zadatak objasniti preobrazbu jednostavnih geometrijskih tijela u druga. $\mathrm{Za}$ tu svrhu sve što njemu treba su trokuti koje može oblikovati u tijela. Vidi: F. M. Cornford, Plato's Cosmology, str. 212-213. Međutim, naše je mišljenje da se viši principi zasnovani na dužinama ne svode na geometriju, a izlaganje o pravilnim tijelima ne svodi se na stereometriju. Jedni i drugi proizlaze iz geometrije, odnosno stereometrije, ne mogu se bez njih razumjeti, ali im više ne pripadaju. Oni čine noetičku matematiku. Isto tako viši principi kao brojevi ne svode se na aritmetiku. Oni iz nje proizlaze i čine treći, najviši oblik noetičke matematike. 
Nakon usporedbe sa suncem, razlaganja crte, te nakon prispodobe o pećini Sokrat i Glaukon počinju novo uspinjanje prema istom cilju. Počinju s propitivanjem nauka koji prema tom cilju vode (Resp. 522a9-b2). Sokrat pita jesu li to možda tjelovježba i muzika? Kaže dalje da je odgoj u tjelovježbi koristan jer nadzire rast i opadanje tijela, ali je vazda zabavljen oko postajućega i propadajućega. Zato on ne može biti nauk koji se traži. Dopuna tjelovježbi je muzika. Ona posredstvom sklada pruža neku pravu usklađenost, posredstvom takta pravu taktičnost, ali ne i znanje.

Prema najvišem znanju vuku četiri nauka. Srodni su jedan drugom, naime svi su matematički. Sokrat daje kratak prikaz svakog pojedinog i kod svakog ističe opasnost da se upravo njime prekrije ono k čemu bi trebao voditi. Prvi je onaj kojim se prislužuju sva umijeća i razmišljanja i znanja tako da je svakome nužno da ga prvo nauči, onaj koji razaznaje jedan, dva i tri, kojim se raspoznaje veliko i maleno. Sokrat ga zove brojem i računom. Međutim, premda ga svi upražnjavaju u svojim potrebama, gotovo se nitko njime ispravno ne služi tako da bi ga vukao spram mišljenja i jestva.

Drugi nauk je geometrija. Ona je manjim svojim dijelom u svemu korisna, posebno u ratovanju, međutim, "promotriti treba onaj veći dalje napredujući dio koji omogućuje da se lakše sagleda ideja dobra« (526e1-2).

U potrazi za sljedećim naukom koji vuče dušu spram istine, Sokrat predlaže astronomiju. Glaukon prihvaća prijedlog te navodi korist od tog nauka. Time što je upotrebiv u određivanju godišnjih doba, mjeseci i godina koristi ratarstvu, brodarstvu i vojskovodsvu. Sokrat kaže da ta korist nije neznatna, ali da je ne treba isticati u strahu pred mnoštvom koje je zaokupljeno samo oko neposredne koristi. Bavljenje astronomijom zbog neposredne koristi

»... ne pročišćava i ponovo ne uspaljuje um već ga upropaštava i osljepljuje. A sačuvati um i stalno ga uspaljivati vrijednije je nego sačuvati tisuće očiju. Njime se, naime, jedinim vidi istina.« $(527 \mathrm{e} 3)$

Prihvaćajući astronomiju kao nauk koji slijedi iza geometrije, Glaukon je skrenuo s puta i mora se vratiti natrag. Ovaj odabir nauka koji mogu imati moć okretanja neobrazovanih i neodgojenih duša nije slučajan. Slučajno nije ni njihovo nizanje.

»Pravilan je slijed nakon drugog prirasta, treći uzimati.«(528b2)

Nakon aritmetike, koja se veže za dužinu, i geometrije, koja se veže uz plohu, slijedi stereometrija, koja se veže uz volumen, odnosno tijelo.

Nauk koji po pravilnom slijedu dolazi iza stereometrije, odnosno astronomije, je harmonika. Ona je srodna astronomiji jer se jedna i druga bave usklađenim kretanjem, $\mathrm{u}$ astronomiji se ono gleda, a u harmonici sluša. Međutim, harmonika daleko nadilazi astronomiju jer se ne odnosi na tjelesno, ali ni na plohu, ni na crtu. Njoj pripada ono prvo u slijedu dimenzija - točka, nijedan od brojeva, nego broj sam. Ne radi se o harmonici kojom se bave neki od pitagorovaca (530e1-531c5). Oni imaju krivi pristup proučavanju sklada te suglasnih i nesuglasnih brojeva. O skladu prosuđuju na osnovi osjetilnog iskustva i naknadno određuju brojeve koji tom skladu pripadaju. Oni ne znaju da su neki brojevi suglasni ili nesuglasni neovisno o iskustvu i ne traže razloge zašto su oni takvi. Postoji, dakle, sustav brojeva čiji su članovi međusobno suglasni i tako čine sklad. Nadalje, razloge za utvrđivanje suglasnosti i sklada ne treba tražiti u osjetilnom iskustvu već u samim brojevima, u svakom pojedinačno i u njihovim odnosima.

Govoreći o suglasnim i nesuglasnim brojevima, Platon ne misli na brojevne odnose kojima se određuju suglasni i nesuglasni muzički intervali, pa ni na 
brojeve koji sudjeluju u izrazu neke analogije već na mogućnost broja da bude ton i kao takav s drugim brojem tonom u suglasju ili nesuglasju. Kako tonovi mogu stvarati sklad, ritam i harmoniju te izvesti glazbu, tako i brojevi izvode muziku. Riječ je, kako već rekosmo, o najvišim počelima koja, kako to stoji u Timeju, slijede iza elementarnih trokuta u ustroju savršenih tijela upisanih u kuglu te crta kao elemenata pravilnih likova upisanih u krug.

\section{Zaključak}

Pozivajući se na tekstove iz Politeje, Fedona i Timeja pokušali smo prikazati na koji je način u Platona Dobro kao svrha svega mislivog gledanje Dobrog u njegovoj chora koju posreduje noetička matematika. Noetička matematika ima četiri razine: razinu geometrijskih tijela, razinu geometrijskih likova, razinu crte te razinu točke, odnosno broja. Na sve četiri razine chora se oblikuje kroz neprekinutu analogiju konstruiranu prema crti iz Politeje, odnosno podjelom crte po krajnjem i srednjem omjeru. Uspjeli smo to djelomično pokazati na razini geometrijskih tijela i na razini crte. Strukturu chore na razini broja samo smo naznačili ukazujući na to da ima upravo deset noetičkih brojeva. Oni su unutar dekade kao sebi srodnog prostora postavljeni na sličan način kao tonovi unutar oktave. Mogu biti suglasni i nesuglasni i ne razlikuju se međusobno samo po veličini.

Govoreći o suglasnim i nesuglasnim brojevima Sokrat ističe kako se znanje o njima ne može steći iz osjetilnog iskustva već iz poznavanja razloga koji su dostatni onome tko te brojeve vidi pa može o njima razmišljati (Resp. 527e4-5). Smatramo da to vrijedi za znanje o prvim počelima na sve četiri razine. Ono se ne može steći samo iz nekog zapisanog teksta o njima i već iz gledanja razloga za koje se pretpostavlja da su u tekstu također prisutni. Interpretirajući Platonove tekstove iz određenog razumijevanja noetičke matematike slijedili smo pomalo neuobičajene tokove interpretacije. Tako smo razlaganje crte u Politeji, neuobičajeno, ali za naše polazište posve prihvatljivo, isključili iz konteksta takozvanih triju usporedbi. Naime, razdiobu crte ne smatramo samo usporedbom već izlaganjem jedne od triju područja noetičke matematike. Crta razdijeljena po neprekinutoj analogiji, onome tko to može vidjeti, pokazuje razliku između razina toposa i chore te dviju razina odnosa: na prvoj velikog i malog a na drugoj osjetljivog i mislivog. Pretpostavljamo da tu gledamo i Dobro sàmo i to kao razliku i svezu na svakoj razini u odnos postavljenih momenata. Nadalje, u prikazu čuvenog mjesta u Fedonu gdje se neposredno gledanje u ono osjetivo uspoređuje gledanjem u pomračeno sunce, neuobičajeno smo pomaknuli naglasak s prvog na drugi dio usporedbe. Prepoznali smo ovdje govor o gledanju sunca, odnosno Dobra, koje se ne događa u njegovoj chora, što omogućuje puno razumijevanje uvjeta njegovog istinskog gledanja. U Platonovom pak prikazu savršenih geometrijskih tijela nismo pratili samo kozmološku raspravu već chorologiju, pravi početak izlaganja prve razine noetičke matematike.

Govoreći o matematici u Platona naša studija pokazuje na potrebu razlikovanja dianoetičke i noetičke matematike. Matematici u Platona do sada se pristupalo bez uvida u tu distinkciju. Smatralo se da se Platon u izričaju svoje dijalektike služi jednom jedinom matematikom (koju mi zovemo dianoetičkom) te da je miješa s nekim pitagorovskim spekulacijama koje bi iz te jedine matematike trebalo isključiti. Nasuprot tome, htjeli smo pokazati da ta matematika koja se veže uz dijalektiku ima svoj poseban ustroj. Pretpostavlja racionalnost dianoetičke matematike jer je put do nje moguć isključivo kroz 
uvažavanje i savladavanje te racionalnosti, ali je u svom dohvatu nadilazi i ima veoma neuobičajen način izlaganja (Tim. 53c4). Jasniji i potpuniji prikaz ovog veoma neuobičajenog načina izlaganja kojim se noetička matematika razlikuje od dianoetičke, zbog opsega ove studije određenog zadanom temom, ovdje nije bio moguć. Za to je predviđeno daljnje dublje zahvaćanje u Platonove tekstove i opširnije izlaganje koncepcije dianoetičke geometrije za koju vjerujemo da je ti tekstovi pretpostavljaju.

\title{
Ćiril Čoh
}

\section{Mathematics and Thought of the Purpose of the Intelligible in Plato's Work}

\begin{abstract}
The paper considers Plato's exposition of the teaching on the Good itself in the Republic, and the teaching about first principles in Timaeus and Phaedo. The starting point is to take Plato's proposition that the Good itself can be observed in its own place, that is, in its chora (Resp. 516b4-7). Such an observation is the observation of the Good itself by itself, and not in the image or in the illusion. The escape into logoi in Phaedo is not only the escape into language that presupposes ideas, but rather the escape into logoi which participate in the continuous analogy. The analogy dominates throughout the exposition of the first principles in Timaeus. Applied to the line in the Republic, it transforms that line from a mere analogy with a geometric example into the line on which the place chora differs from the place topos. Such a line enables watching the Good itself in its own chora. It belongs to a different mathematics which we can call noetic.
\end{abstract}

\section{Key words}

Plato, first principles, chora, topos, escape into logoi, continuous analogy, Plato's line, ideal numbers, noetic mathematics 